\title{
GENETIC DIVERSITY OF ONE CULTIVAR AND 29 GENOTYPES OF TOBACCO BASED ON MORPHOLOGICAL AND YIELD PROPERTIES
}

\author{
M. Camlica ${ }^{*}$ and G. Yaldiz \\ Department of Field Crops, Faculty of Agriculture and Natural Sciences, Bolu Abant İzzet Baysal University, Bolu, \\ Turkey. \\ Corresponding Author's E-mail: mcamlica25@outlook.com
}

\begin{abstract}
Tobacco (Nicotiana tabacum) is one of the cash and industrial crops commonly grown throughout the world. This plant is important for the agriculture sector in Turkey, with high-quality varieties being produced in different regions of the country. This study aimed to examine important morphological properties and yield of a cultivar and some genotypes of tobacco under the conditions of Bolu province in Turkey in 2015 and 2016. Genetic variability parameters such as GCV (\%), PCV (\%), GA and heritability were conducted to provide the best image of the tobacco cultivar and genotypes. GCV values were near to PCV values for the properties like DFT, DT and OV indicative high contribution of genotypic effect for phenotypic expression of such properties. These properties had moderately high heritability with $79.98 \%$, $73.95 \%$ and $79.51 \%$, respectively. The highest fresh leaf weight was observed in the AR-1 cultivar $\left(525.0 \mathrm{~kg} \mathrm{da}^{-1}\right)$ and ESR-7 genotype (646.30 kg da $\left.{ }^{-1}\right)$ in the first year and BSR-3 (358.22 kg da $)$ and ESR-6 (320.19 kg da $\left.\mathrm{kg}^{-1}\right)$ genotypes in the second year. A correlation analysis was also conducted between these traits of tobaccos. Highly significant and positive correlations were found between DFT-DT, LL-LW and FLW-DLW. A dendrogram was constructed to determine the relationships between the investigated plants based on morphological properties and yield values. One cultivar and 29 genotypes were located in two main groups as A (14 genotypes and one cultivar) and B (15 genotypes). The genotypes included same region were located in different groups.
\end{abstract}

Keywords: Cash crop, correlation analysis, dendrogram, industrial plant, Nicotiana tabacum.

https://doi.org/10.36899/JAPS.2020.2.0038

Published online March 02, 2020

\section{INTRODUCTION}

Tobacco (Nicotiana tabacum) is an annual plant belonging to the Solanaceae (nightshade) family (Burun and Emiroglu, 1988). It is a rich source of alkaloids, such as nicotine and has been used as a medicinal plant and social stimulant throughout history. Tobacco is also one of the most substantial industrial and cash crops for many countries (Rezitis and Brown, 1999). According to the Food and Agriculture Organization (FAO) report in 2016, Turkey is among the top ten countries in terms of cultivation area of tobacco, along with China, Brazil, Indonesia, and the United States of America (FAO, 2018). In 2018, the tobacco production was 7.2 million tons in approximately 4 million ha in the world and 80,000 tons in nearly 950,000 da in Turkey. In the same year, Turkey exported and imported 57,500 and 61,000 tons of tobacco, respectively. The highest production and cultivation area was observed in the Aegean region (699,028 da, 52,565 ton), and the highest yield was obtained from the Black Sea region $\left(115.33 \mathrm{~kg} \mathrm{da}^{-1}\right)$ (FAO, 2018; TSI, 2018).

Different tobacco varieties are produced in Turkey to meet the demand of domestic consumption and foreign sales, and these varieties vary according to the regions of cultivation (Peksuslu et al., 2012). Turkish tobacco maintains its reputation in the world market due to its high quality of blending and smoking. Morphological characterization has been reported to differ according to the geographical region where tobacco is grown (TTS, 2006). Most of the information available on morphological development of tobacco genotypes is based on comparisons between cultivars grown in different geographic zones; however, there is not extensive data obtained from different regions within the same area. Such information is useful for cultivar selection and development, as well as providing an understanding of the differences between genotypes.

There are important tools to determine the variability and extend of characters in plant breeds to assist the conduct of studies in plant breedings. Therefore, the estimation of genetic parameters such as heritability, genetic advance, phenotypic and genotypic coefficient variations are used for research to generate high value knowledge (Lira et al., 2017).

Heritability provides more identification about the genetic improvement together with genetic advance. Genetic advance helps the improvement of character in genotypic value for the new population compared with the base population under one cycle of selection at given selection intensity (Singh, 2001). 
The main objectives of this study were to, 1) determine the morphological characteristics and yield of local tobacco cultivar and genotypes, 2) evaluate the genetic variability of tobacco cultivar and genotypes based on examined properties using genetic parameters and dendrogram, 3) calculated the correlations between morphological characteristics and yield and relate them to the performance of each genotype and cultivar for a two years average, 4) identify and select the most promising genotypes for future breeding work.

\section{MATERIALS AND METHODS}

The field study was carried out in Bolu ecological conditions to determine the adaptation, morphological properties and yield of 29 genotypes and three cultivars of tobacco (AR-1, Burley 94 and Virginia 90) during 2015 and 2016 growing seasons (Table 1), but the Burley 94 and Virginia 90 cultivars did not adapt and grow.

Seedlings were grown in a greenhouse with three replications in pots $(10 \times 12 \mathrm{~cm})$, containing equal amounts sand-turf-soil mixture $(1: 1: 1)$ in May in both years. During the growth period, routine practices were undertaken, such as weed control and disease and pest management. After sowing, when the seedlings reached 10-15 cm in height (Kinay, 2010; Kinay and Yilmaz, 2016), they were transplanted in the trial area on 3rd July 2015 and 7th July 2016 in open-field conditions. The experiment was carried out on the experimental field of the research and application area of the Department of Field Crops, Natural and Agricultural Sciences of Bolu
Abant İzzet Baysal University (Turkey) (4044'44' N, $31^{\circ} 37^{\prime} 45^{\prime \prime}$ E, $881 \mathrm{~m}$ altitude). The soil was clay-loam with a $\mathrm{pH}$ value of $7.8,4.7 \%$ organic matter content, 10.3 $\mathrm{mg} \mathrm{kg}$ phosphorus ratio, and $235 \mathrm{mg} \mathrm{kg}^{-1}$ potassium ratio (BDAF, 2015). The average climatic data were recorded as $19.10{ }^{\circ} \mathrm{C}$ temperature, $259.1 \mathrm{~mm}$ rainfall, and $71.8 \%$ humidity during the vegetation period for 2015 , and $18.0^{\circ} \mathrm{C}$ temperature, $208.8 \mathrm{~mm}$ rainfall, and $70.86 \%$ humidity during the vegetation period for 2016 (TSM, 2016). The experiment was based on a randomized complete block design with three replicates. Each experimental plot consisted of three rows that were a row-to-row distance of $0.4 \mathrm{~m}$ and plant to-plant distance of $0.15 \mathrm{~m}$ and plot size $2.52 \mathrm{~m}^{2}$. Distance between the blocks a meter was arranged. The total field experiment was conducted in $298.80 \mathrm{~m}^{2}$. Four $\mathrm{kg} \mathrm{da}^{-1}$ diammonium phosphate (DAP) and $2 \mathrm{~kg} \mathrm{da}^{-1}$ ammonium nitrate (AN) were applied to the plots as a base and top fertilizer. The tobacco cultivar and the genotypes were regularly irrigated in vegetation periods and controlled against weeds. Harvesting was undertaken early in the morning or after 5: 00 p.m. in the evening from September 10 to October 8 in the first year and from September 15 to October 12 (three times) in the second year (Er and Yildiz, 2014). After harvesting, the leaves were dried in laboratory conditions. During the vegetation period, days to flowering time (DFT), number of days of topping (DT), plant height (PH), leaf width (LW) and length (LL), and number of leaves (NL) were determined as described in the literature (Ozel and Ozguven, 1996; Esendal et al., 2001; Gencer, 2002; Camas et al., 2007; Kinay, 2010; Kurt, 2011).

Table 1. List of tobacco genotypes and cultivar used in the current study.

\begin{tabular}{|c|c|c|c|c|}
\hline $\mathbf{N}$ & Region- & & & Geographic coordinates \\
\hline $\mathbf{0}$ & Code & Genotypes/cultivar names & Obtained place or person & Latitude $\quad$ Longitude \\
\hline 1 & AR-1 & Akhisar 97 & Manisa/Cultivar & $27^{\circ} 50^{\prime} 11.8320^{\prime \prime} \mathrm{E}$ \\
\hline 2 & AR-2 & Akhisar-Sarılar & Manisa/Akhisar/Sarılar/Ufuk Özcan & $39^{\circ} 6 ' 26.9100^{\prime \prime} \mathrm{N}$ \\
\hline 3 & MR-1 & Agonya-Yarış Village & $\begin{array}{l}\text { Çanakkale/Agonya/Yarış Village/Anıl } \\
\text { Özyurt }\end{array}$ & $39^{\circ} 47^{\prime} 1.6332^{\prime \prime} \mathrm{N} \quad 27^{\circ} 15^{\prime} 51.7320^{\prime \prime} \mathrm{E}$ \\
\hline 4 & ESR-1 & B. Çelikhan 97 & Adiyaman/Çelikhan & $38^{\circ} 1 ' 59.0520^{\prime \prime} \mathrm{N} \quad 38^{\circ} 14^{\prime} 13.9128^{\prime \prime} \mathrm{E}$ \\
\hline 5 & BSR-1 & Bafra Gökçeağaç & Samsun/Bafra/Gökçeağaç/Şefik Kara & $41^{\circ} 32^{\prime} 45.9204^{\prime \prime} \mathrm{N} \quad 35^{\circ} 45^{\prime} 41.4324^{\prime \prime} \mathrm{E}$ \\
\hline 6 & BSR-2 & Bafra Paşaşeyh & Samsun/Bafra/Paşaşeyh/Cemil Yüksel & $41^{\circ} 28^{\prime} 50.8260^{\prime \prime} \mathrm{N} \quad 35^{\circ} 44^{\prime} 18.0888^{\prime \prime} \mathrm{E}$ \\
\hline 7 & MR-2 & Balıkesir (AARI, 42986) & AARI & - \\
\hline 8 & MR-3 & Balıkesir (AARI, 64073) & AARI & - \\
\hline 9 & ESR-2 & Bitlis Mutki Erler Village-1 & Bitlis/Mutki/Erler Village/Sait Sülün & $38^{\circ} 28^{\prime} 46.7472^{\prime \prime} \mathrm{N} \quad 41^{\circ} 43^{\prime} 56.5536^{\prime \prime} \mathrm{E}$ \\
\hline 10 & ESR-3 & Bitlis Mutki Erler Village-2 & Bitlis/Mutki/Erler Village/Yusuf Kesim & $38^{\circ} 28^{\prime} 46.7472^{\prime \prime} \mathrm{N} \quad 41^{\circ} 43^{\prime} 56.5536^{\prime \prime} \mathrm{E}$ \\
\hline 11 & MR-4 & Bursa (AARI, 42884) & AARI & - \\
\hline 12 & MR-5 & Bursa (AARI, 78215) & AARI & - \\
\hline 13 & ESR-4 & Bitlis (AARI, 42076) & AARI & - \\
\hline 14 & ESR-5 & Bitlis (AARI, 80111) & AARI & - \\
\hline 15 & ESR-6 & Eski Tütün-Hatay & Hatay & $36^{\circ} 10^{\prime} 34^{*} \mathrm{E}$ \\
\hline 16 & ESR-7 & Hatay (AARI, 42126) & AARI & - \\
\hline 17 & ESR-8 & Hatay (AARI, 42128) & AARI & - \\
\hline 18 & ESR-9 & Hatay (AARI, 42132) & AARI & - \\
\hline 19 & AR-3 & Manisa (AARI, 64062) & Aegean Agricultural Research Institute & $38^{\circ} 36^{\prime} 50.5188^{\prime \prime} \mathrm{N} \quad 27^{\circ} 25^{\prime} 46.4232^{\prime \prime} \mathrm{E}$ \\
\hline
\end{tabular}


20 ESR-10 Muş (AARI, 42094)

21 AR-4 Salihli Kale Village

22 BSR-3 Samsun (AARI, 49184)

23 BSR-4 Samsun (AARI, 49188)

24 BSR-5 Samsun (AARI, 49219)

25 BSR-6 Samsun (AARI, 49224)

26 BSR-7 Samsun Tekkeköy Hamzalı

27 BSR-8 Samsun Terme Akçay

28 BSR-9 Samsun Tekkeköy Balcalı

29 BSR-10 Samsun Tekkeköy Kahyalı

30 ESR-11 Yayladağı Sebenoba
AARI

Manisa/Salihli/Kale Village/İbrahim

Zeybek

AARI

AARI

AARI

AARI

Samsun/Tekkeköy/Hamzalı/Mustafa

Anıl

Samsun/Terme/Akçay/Mümin Bayram

Samsun/Tekkeköy/Balcalı/Ali Doğru

Samsun/Tekkeköy/Kahyalı/Osman Kul

Hatay/Yayladağı/Sebenoba/Ayșe Şahin $38^{\circ} 43^{\prime} 18.6780^{\prime \prime} \mathrm{N} \quad 28^{\circ} 8^{\prime} 17.9700^{\prime \prime} \mathrm{E}$

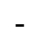

$41^{\circ} 12^{\prime} 19.8756^{\prime \prime} \mathrm{N} 36^{\circ} 32^{\prime} 15.2844^{\prime \prime} \mathrm{E}$

$41^{\circ} 8^{\prime} 0.7332^{\prime \prime} \mathrm{N} \quad 37^{\circ} 9^{\prime} 22.2264^{\prime \prime} \mathrm{E}$

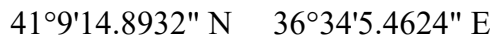

$41^{\circ} 10^{\prime} 21.5508^{\prime \prime} \mathrm{N} \quad 36^{\circ} 32 ' 21.6564^{\prime \prime} \mathrm{E}$ $36^{\circ} 2^{\prime} 48.2424^{\prime \prime} \mathrm{N} \quad 36^{\circ} 1^{\prime} 15.0384^{\prime \prime} \mathrm{E}$

AARI: Aegean Agricultural Research Institute, AR: Aegean Region, MR: Marmara Region, ESR: Eastern and Southeastern Anatolia Region, BSR: Black Sea Region.

The data obtained were subjected to an analysis of variance and the mean values were compared using the least significant difference (LSD) method (Steel et al., 1997).

Genetic parameters were determined by the formula given by Malek et al. (2014) and Lira et al. (2017). These parameters were calculated using the following equations:

(i) $\mathrm{GV}\left(\sigma_{\mathrm{G}}^{2}\right)=(\mathrm{MSG}-\mathrm{MSE}) / r$, GV: Genotypic variance, MSG: Mean square of tested genotypes, MSE: Mean square of error, $r$ : refers to the number of replications,

(ii) MSE: $\sigma_{\mathrm{E}}^{2}$,

(iii) $\mathrm{PV}\left(\sigma_{\mathrm{P})}^{2}=\sigma_{\mathrm{G}}^{2}+\sigma_{\mathrm{E}}^{2}, \mathrm{PV}\right.$ : Phenotypic variance,

(iv) PCV (phenotypic coefficient of variation) $=\sqrt{\sigma_{\mathrm{p}}^{2}} / X \times 100, \sigma_{\mathrm{p}}^{2}$ : the phenotypic component of variance, $X$ : the mean of the property,

(v) GCV (genotypic coefficient of variation) $=\sqrt{ } \sigma^{2}{ }_{\mathrm{G}} / X$ $\times 100$,

(vi) $h_{\mathrm{B}}^{2}$ (heritability) $=\sigma_{\mathrm{G}}^{2} / \sigma_{\mathrm{p}}^{2}$,

(vii) GA (as \% of the mean) $=K \times \sqrt{ } \sigma_{\mathrm{P}}^{2} / X \times h^{2}{ }_{\mathrm{B}} \times 100, K$ (the standardized selection intensity $)=2.06($ at $5 \%$ selection intensity).

(viii) $\mathrm{SA}\left(\mathrm{r}_{\mathrm{g}^{\wedge} \mathrm{g}}\right)=1-1 / \mathrm{F}, \mathrm{F}=\mathrm{QMg} / \mathrm{QMe}, \mathrm{SA}$ : Selective accuracy.

Furthermore, the Pearson correlation analysis was carried out following Knapp (2017). The dendrogram was used to show the hierarchy of clusters and determine the genetic variability among tobacco cultivar and genotypes based on examined properties via XLSTAT program (Espinoza et al., 2012). All statistical analyses were conducted using XLSTAT software program at the 0.01 level.

\section{RESULTS AND DISCUSSION}

Variability and Genetic Parameters of Tobacco cultivar and Genotypes: ANOVA showed that mean squares and mean squares error due to genotypes were highly significant $(P \geq 0.01)$ for all the nine properties of tobacco cultivar and genotypes in average of two experiment years (Table 2). These results revealed highly significant genotypic variations for all examined properties. Phenotypic and genotypic coefficients of variation (PCV and GCV), broad sense heritability, and genetic advance were estimated for all the properties (Table 2). GV values ranged from 0.06 for OV to 648.42 for FLW while phenotypic variance values changed between 0.07 to 6458.98 for OV and FLW, respectively. The highest GCV was seen in NL (14.47\%) and the lowest GCV was recorded in DT $(4.39 \%)$. The highest PCV was observed from FLW (27.94\%) and the lowest PCV was observed from DFT (5.09\%). The GCV and PCV of PH (10.62 and 17.99\%), LL (10.42 and 16.45\%) LW (12.80 and 16.88\%), OV (12.12 and 13.59\%), NL (14.47 and 23.46\%), FLW (8.85 and 27.94\%) and DLW (12.65 and 22.38\%) were higher compared to DFT (4.55 and $5.09 \%)$ and DT (4.39 and 5.10\%).

All the properties exhibited high heritability which ranged from $10.04 \%$ in FLW to $79.98 \%$ in DFT. Among the properties, PH, LL, NL, FLW and DLW had relatively low heritability under $50 \%$ compared to others. The genetic advance as percent of mean (GA\%) ranged from $5.78 \%$ in $\mathrm{FLW}$ to $22.26 \%$ in OV. Among the properties, OV, LW and NL showed higher percentages of genetic advance (Table 2).

PCV and GCV values more than $20 \%$ are regarded as high and values between $10 \%$ and $20 \%$ to be medium, whereas values less than $10 \%$ are considered to be low (Deshmukh et al., 1986). It was noted that heritability values greater than $80 \%$ were very high, values from $60-79 \%$ were moderately high, values from $40-59 \%$ were medium and values less than $40 \%$ were low (Singh, 2001). Genetic advance is grouped as low $(<$ $10 \%)$, moderate $(10-20 \%)$ and high $(>20 \%)$ by Johnson et al. (1955).

According to obtained results, DFT, DT and OV were found as moderately high, LL and LW were found as medium and other properties were seen as low. Our GCV and PCV results were found less than $20 \%$ except GCV of NL and FLW. DFT and DT were found less than 
$10 \%$ as low and other properties were found between $10-\quad 20 \%$ as medium.

Table 2. MS, MSE, $F$ values and genetic parameters of nine different characters of tobacco cultivar and genotypes.

\begin{tabular}{llllllllll}
\hline $\begin{array}{l}\text { Properties/ Genetic } \\
\text { parameters }\end{array}$ & DFT & DT & PH & LL & LW & OV & NL & FLW & DLW \\
\hline MS & 72.47 & 64.75 & 453.59 & 17.93 & 6.51 & 0.19 & 30.43 & 7755.81 & 257.43 \\
MSE & 5.58 & 6.80 & 174.15 & 5.96 & 1.28 & 0.01 & 10.71 & 5810.56 & 106.85 \\
F & 12.98 & 9.52 & 2.60 & 3.01 & 5.07 & 12.64 & 2.84 & 1.33 & 2.41 \\
GV & 22.30 & 19.31 & 93.15 & 3.99 & 1.74 & 0.06 & 6.57 & 648.42 & 50.19 \\
PV & 27.88 & 26.12 & 267.30 & 9.95 & 3.03 & 0.07 & 17.28 & 6458.98 & 157.04 \\
$\boldsymbol{h}_{\text {B }}^{2}$ & 79.98 & 73.95 & 34.85 & 40.13 & 57.57 & 79.51 & 38.04 & 10.04 & 31.96 \\
GCV (\%) & 4.55 & 4.39 & 10.62 & 10.42 & 12.80 & 12.12 & 14.47 & 8.85 & 12.65 \\
PCV (\%) & 5.09 & 5.10 & 17.99 & 16.45 & 16.88 & 13.59 & 23.46 & 27.94 & 22.38 \\
GA (\%) & 8.70 & 7.77 & 11.74 & 13.60 & 20.01 & 22.26 & 18.38 & 5.78 & 14.74 \\
SA & 0.96 & 0.95 & 0.78 & 0.82 & 0.90 & 0.96 & 0.81 & 0.50 & 0.76 \\
\hline
\end{tabular}

MS: Mean Square, MSE: Mean Square Error, F: F value, GV: Genotypic Variance, PV: Phenotypic Variance, $h^{2}$ : Heritability, GCV: Genotypic Coefficient of Variation, PCV: Phenotypic Coefficient of Variation, GA: Genetic Advance, SA: Selective Accuracy

\section{Morphological properties and yield values}

DFT (days): The AR-1 cultivar and different tobacco genotypes differed statistically significantly at $1 \%$ probability level for DFT (Table 3). The shortest and longest DFT were recorded for ESR-4 genotype (92.0 and 97.33 days) and ESR-8 genotype (114.67, 116.66 days), in 2015 and 2016 years, respectively. The average DFT was determined as 102.20 days in 2015 and 105.42 days in 2016, and the DFT of the cultivar (AR-1) was over the average of years with 103.29 and 106.24 days. Concerning different regions, the averages of DFT in 2015 and in 2016 were 107.25, 109.17 days for the Aegean Region (AR), 104.80, 107.40 days for the Marmara Region (MR), 101.85, 105.09 days for the Eastern and Southeastern Region (ESR), and 99.27, 103.30 days for the Black Sea Region (BSR), respectively (Table 4). These findings were similar to those reported by Gencer (2002) (54-117 days), but different from those determined by Peksuslu (1998) (4974 days). This difference is due to the light or photoperiod times of Bolu, as well as genetic characteristics of tobacco (Mouradov et al., 2002)

DT (days): Differences in the DT of the investigated tobacco cultivar and genotypes were statistically significant (Table 3). DT ranged from 88 to 111 days in 2015 and from 95.0 to 113.67 days in 2016, with the earliest was observed in the ESR-4 genotype and the latest was seen in AR-4 genotype in first year and BSR-1 genotype had the shortest DT and AR-4 genotype had the earliest DT in second year. The results also revealed that the tobacco cultivar and genotypes differed in DT time between the different geographical regions of Turkey. The highest mean DT values were obtained from AR as 103.92 and106.33 days both two years. The lowest mean DT values were seen in BSR with 96.10 and 100.07 days in 2015 and 2016 years, respectively (Table 4). The cultivar, AR-1, was also observed to have a shorter DT time (98.0 days) than the regions average of the genotypes.

PH (cm): There were significant differences between the genotypes and cultivar in the assessment of $\mathrm{PH}$ for both years. The average $\mathrm{PH}$ varied between $43.17 \mathrm{~cm}$ and $142.00 \mathrm{~cm}$ during both years (Table 3). The longest average PH was obtained from AR-1 $(142.00 \mathrm{~cm})$ in 2015 and BSR-3 $(93.51 \mathrm{~cm})$ in 2016 . The shortest average PH was recorded in AR-2 $(80.82 \mathrm{~cm})$ in 2015 and ESR-6 $(43.17 \mathrm{~cm})$ in 2016 (Table 3). The average PH values were 110.97 and $63.50 \mathrm{~cm}$ for AR, 125.57 and $67.52 \mathrm{~cm}$ for MR, 105.91 and $67.84 \mathrm{~cm}$ for ESR, and 119.76 and $66.65 \mathrm{~cm}$ for BSR in 2015 and 2016, respectively (Table 4). The results of the present study agreed with those of previous studies reporting a $\mathrm{PH}$ range of 37.79 to 159.57 cm (Usturali et al., 1998; Gencer, 2002; Kucukozden et al., 2002; Korkmaz, 2006; Ekren, 2007; Kurt and Ayan, 2014; Yagac, 2015; Kinay and Yilmaz, 2016).

LL (cm): Significant differences were observed in both years for LL of the cultivar and genotypes examined in this study (Table 3). Generally, LL varied from $12.78 \mathrm{~cm}$ to $28.67 \mathrm{~cm}$. The longest LL was determined in BSR-2 $(21.44 \mathrm{~cm})$ in 2015 and ESR-1 $(28.67 \mathrm{~cm})$ in 2016 . The shortest LL was found in AR-4 $(12.78 \mathrm{~cm})$ in 2015 and BSR-7 $(15.90 \mathrm{~cm})$ in 2016 . When the tobacco cultivar and genotypes were compared between different geographical regions of Turkey, the longest LL was seen in ESR with an average of 18.36 and $23.96 \mathrm{~cm}$ in 2015 and 2016, respectively (Table 4). The AR-1 cultivar had a shorter LL than the ESR genotypes in 2015 and longer LL than the AR genotypes in 2016. In a previous report on tobacco LL, the values varied between 7.68 and 18.63 cm (Kucukozden et al., 2002; Kurt and Ayan, 2014). In 
other studies, the LL ranges of tobacco were reported as 10.04-12.14 cm (Ekren, 2007), 11.00-12.56 cm (Korkmaz, 2006), 9.51-13.31 cm (Usturali et al., 1998), and 13.33-17.00 $\mathrm{cm}$ (Yagac, 2015).

The data obtained from the current study were generally similar to the literature, except the work by Ekren (2007) and Korkmaz (2006).

The leaf length of Turkish tobacco is divided into three types as small $(2-15 \mathrm{~cm})$, medium $(16-25)$, and large $(>26 \mathrm{~cm})$. It is generally stated that large-leaved tobacco is associated with humid areas while smallleaved tobacco with arid climatic conditions (TEA, 2018).

Our results showed that LL of ESR-1 $(28.67 \mathrm{~cm})$ and BSR-3 $(26.67 \mathrm{~cm})$ were found as large in 2016. 16 genotypes were found as medium in 2015 and 27 genotypes were found as medium in 2016 and 14 genotypes were seen as small in 2016 and only one genotype (BSR-7) was found as small with $15.90 \mathrm{~cm}$ in 2016. The highest average LL among the regions belonged to ESR because the altitude of Bolu province is close to the remaining provinces, except Hatay. The differences between the two years can be explained by humidity being higher in 2016 than in 2015 (TEA, 2018).

LW (cm): This parameter varied statistically significantly in both years $(\mathrm{P} \geq 0.01)$. The $\mathrm{LW}$ value ranged from 7.71 to $12.58 \mathrm{~cm}$ in 2015 and 7.60 to 14.00 $\mathrm{cm}$ in 2016 (Table 3). In 2015, the highest were determined in ESR-10 $(12.58 \mathrm{~cm})$, MR-5 $(12.29 \mathrm{~cm})$ and ESR-4 $(12.26 \mathrm{~cm})$ genotypes. The lowest were found in BSR-9 $(7.71 \mathrm{~cm})$, AR-2 $(7.85 \mathrm{~cm})$ and AR-3 $(7.86 \mathrm{~cm})$ genotypes. In 2016, LW had the highest values in MR-5 $(14.00 \mathrm{~cm})$ and ESR-9 $(13.50 \mathrm{~cm})$ genotypes and had the lowest in the AR-2 $(7.60 \mathrm{~cm})$ genotype and the AR-1 $(7.73 \mathrm{~cm})$ cultivar. Among the regions of Turkey, the mean values were found as 8.01 and $8.32 \mathrm{~cm}$ in AR, 9.93 and $11.30 \mathrm{~cm}$ in MR, 11.05 and $11.50 \mathrm{~cm}$ in ESR, and 9.37 and $10.32 \mathrm{~cm}$ in BSR in 2015 and 2016, respectively (Table 4). This indicated that the highest LW averages were obtained from the ESR tobaccos. In previous studies, LW was reported as $8.06-9.20 \mathrm{~cm}$ by Kurt and Ayan (2014) and $7.00-9.33 \mathrm{~cm}$ by Yagac (2015). Other researchers observed in LW range of 3.76 to $6.33 \mathrm{~cm}$ (Usturali et al., 1998; Kucukozden et al., 2002; Ekren 2007). The data obtained from the current study were similar to those of Kurt and Ayan (2014), Yagac (2015), and Kinay and Yilmaz (2016), but much higher than reported by other researchers. It is suggested that the LW of tobacco is affected by genetic characteristics of plants, and environmental and growing conditions (Peksuslu, 1998).

OV: Significant differences were seen among the tobacco cultivar and genotypes in 2015 and $2016(\mathrm{P} \geq 0.01) \mathrm{OV}$ varied from 1.47 to 2.53 and 1.57 to 2.96 in 2015 and 2016, respectively (Table 3 ). The highest values were found in the ESR-1 genotype in both years and the lowest was seen in the MR-5 genotype in 2015 and MR-1 in 2016. Concerning the regional analysis, the average OV was calculated as 1.86 and 2.09 for AR, 1.79 and 1.85 for MR, 1.92 and 2.12 for ESR, and 1.97 and 2.03 for BSR in 2015 and 2016, respectively (Table 4). The OVs of this cultivar were higher than the 2015 and 2016 averages of the geographical regions. OV was also mostly over 1.90 , except the MR tobaccos, AR-4, BSR-1, 3,5 and ESR$2,3,8,9$ in both years. These results are generally consistent with the findings of Ekren (2007).

NL (number): Statistically significant differences were found among the tobacco genotypes and cultivar for NL (Table 5). Generally, NL varied between 13.67 and 31.20 number in 2015 and 10.33 and 31.89 number in 2016 . The highest NL was seen in BSR-2 (31.20 number) and BSR-4 (31.89) and the lowest were found in MR-4 (13.67 number) and ESR-3 (10.33 number) in 2015 and 2016, respectively. Among the regions, NL was found as 23.38 and 14.42 number for AR, 23.30 and 14.18 number for MR, 17.86 and 12.58 number for ESR, and 22.98 and 16.22 number for BSR in 2015 and 2016, respectively (Table 6). The NL values of the AR-1 cultivar were 28.20 number in 2015 and 15.30 number in 2016.

It was observed that the NL values of first year were found higher than second year. Previous studies on tobacco grown in the area reported that NL varied between 24.00 and 41.33 number (Usturali et al.,1998; Kucukozden et al., 2002; Korkmaz 2006; Kurt and Ayan 2014; Yagac 2015). Ekren (2007) reported that NL ranged from 16.58 to 24.62 . The results obtained from the present study are similar to those reported in previous research, except the work of Kurt and Ayan (2014). The differences in NL between the genotypes and cultivar may be due to the temperature variations between the two experimental years.

FLW $\left(\mathrm{kg} \mathrm{da}^{-1}\right)$ : The statistical evaluation of the FLW of the tobacco genotypes and cultivar used in the study is given in Table 5. According to this data, there were different groups in terms of FLW among the cultivar and genotypes and the FLW values of these groups also differed between the two years. The average FLW was calculated as 364.0 and $188.16 \mathrm{~kg} \mathrm{da}^{-1}$ in 2015 and 2016 , respectively. The FLW of the tobacco genotypes and cultivar varied between 90.11 and $646.30 \mathrm{~kg} \mathrm{da}^{-1}$ in both years. The highest FLW was obtained from the AR-1 $\left(525.00 \mathrm{~kg} \mathrm{da}^{-1}\right)$ cultivar and the ESR-7 genotype (646.30 $\left.\mathrm{kg} \mathrm{da}^{-1}\right)$ in the first year and was observed from BSR-3 $\left(358.22 \mathrm{~kg} \mathrm{da}^{-1}\right)$ and ESR-6 (320.19 kg da $\left.{ }^{-1}\right)$ in the second year. The lowest FLW was seen in ESR-4 $(158.80 \mathrm{~kg}$ da $\left.{ }^{1}\right)$ in 2015 and BSR-9 $\left(90.11 \mathrm{~kg} \mathrm{da}^{-1}\right)$ in 2016. When the average FLW of the tobacco cultivar and genotypes were compared between the regions, as the highest FLW was found $409.11 \mathrm{~kg} \mathrm{da}^{-1}$ in ESR, and $217.70 \mathrm{~kg} \mathrm{da}^{-1}$ in MR in 2016 (Table 6). The FLW average of the AR-1 cultivar 
$525.00 \mathrm{~kg} \mathrm{da}{ }^{-1}$ was above the regional average in 2015 . These variations in FLW obtained from the tobacco genotypes and cultivar may have been caused by the differences in the climatic data of the two experimental years. In previous reports, the FLW of tobacco was found to be 363.54-382.29 kg da ${ }^{-1}$ (Yagac, 2015) and 506-1050 $\mathrm{kg} \mathrm{da}^{-1}$ (Kucukozden et al., 2002). In relation to the literature, our results were most similar to those of Yagac (2015), but differed from those of Kucukozden et al. (2002). This can be attributed to the differences in the ecological and growing conditions and the genetic structure of the investigated cultivar and genotypes.

DLW ( $\left.\mathrm{kg} \mathrm{da}^{-1}\right)$ : The statistics on the tobacco cultivar and genotypes in terms of DLW evaluation and groupings are shown in Table 5. Statistically significant differences were found between the cultivar and genotypes in both years. The average DLW was determined as $76.96 \mathrm{~kg} \mathrm{da}^{-1}$ in the first year and $35.01 \mathrm{~kg} \mathrm{da}^{-1}$ in the second year. The highest DLW was obtained from the AR-1 cultivar $\left(119.74 \mathrm{~kg} \mathrm{da}^{-1}\right)$ in 2015 and the BSR-4 genotype (68.87 $\left.\mathrm{kg} \mathrm{da}^{-1}\right)$ in 2016. The lowest DLW was observed in the ESR-11 genotype (49.52 kg da ${ }^{-1}$ ) in 2015 and AR-3 $\left(21.85 \mathrm{~kg} \mathrm{da}^{-1}\right)$ in 2016. DLW was found to be more than twofold in 2015 compared with 2016. When the DLW of the tobacco genotypes were examined between the regions, the highest DLW was found in ESR $(79.23 \mathrm{~kg}$ $\left.\mathrm{da}^{-1}\right)$, followed by AR (76.86 kg da $\left.{ }^{-1}\right)$, MR $\left(76.19 \mathrm{~kg} \mathrm{da}^{-}\right.$ $\left.{ }^{1}\right)$, and BSR (74.88 kg da $\left.{ }^{-1}\right)$ in 2015. In 2016, the highest DW was seen in MR (37.99 kg da $\left.\mathrm{kg}^{-1}\right)$, followed by BSR $\left(35.91 \mathrm{~kg} \mathrm{da}^{-1}\right)$, AR (33.20 kg da $\left.{ }^{-1}\right)$, and ESR (33.96) (Table 6). The tobacco genotypes in ESR had the highest average DLW in for the first year, but lowest in the second year.

Previous studies on tobacco plants grown in the area reported DLW to vary between $85 \mathrm{~kg} \mathrm{da}^{-1}$ and $244.00 \mathrm{~kg} \mathrm{da}^{-1}$ (AARI, 2002; Kucukozden et al., 2002; Kurt and Ayan, 2014; Yagac, 2015). The DLW results obtained from the present study were partially similar to those reported in previous studies concerning the 2015 data, but our 2016 values were lower (Kucukozden et al., 2002; Kurt and Ayan, 2014; Yagac, 2015). This is considered to be due to the differences in genetic and growing conditions. Furthermore, the variations in DLW obtained from the genotypes and cultivar in this study may be the result of climatic differences between the two experimental years.

Correlation study for the tobacco genotypes and cultivar: Table 7 showed correlation analysis of morphological traits and yield components of tobacco genotypes and cultivar between the average of two experiment years. DFT was highly significantly and positively correlation with DT $(\mathrm{r}=0.927)$, LL with LW $(\mathrm{r}=0.520)$, and FLW with DLW $(\mathrm{r}=0.512)$. Similarly, a highly significant, but negative correlation was observed for $\mathrm{PH}$ and $\mathrm{LW}$ with $\mathrm{OV}(\mathrm{r}=-0.548$ and $\mathrm{r}=-0.532)$. $\mathrm{PH}$ was positively correlated with NL $(\mathrm{r}=0.381)$, LW $(\mathrm{r}=0.441)$ and DLW $(\mathrm{r}=0.385)$. Similarly, LL exhibited a positive correlation with OV $(\mathrm{r}=0.406)$ and FLW $(\mathrm{r}=0.405)$ and LW was positively correlated with FLW $(\mathrm{r}=0.423)$ and DLW $(\mathrm{r}=0.368)$. DT was also significantly and negatively correlated with LW $(\mathrm{r}=-0.410)$. No significant correlation was observed for the remaining variables.

Evaluation of genetic diversity: A dendrogram was constructed to determine the strength of the correlation between the morphological and yield properties of the tobacco genotypes and cultivar (Fig. 1). According to the results, the sample was divided into two groups: Group A and Group B, each containing two subgroups (A1, A2, B1, B2). Group A consisted of the 14 genotypes from MR $(n=3)$, ESR $(n=6)$, BSR $(n=5)$ and one cultivar (AR-1). Subgroup A1 had 7 genotypes and one cultivar and subgroup A2 had 7 genotypes from BSR $(\mathrm{n}=3)$, ESR $(n=2)$ and MR $(n=2)$. Group B was divided 2 sub group (B1-B2) and totally it had 15 tobacco genotypes. Subgroup B1 had four genotypes from BSR $(\mathrm{n}=2)$, ESR $(\mathrm{n}=1)$ and $\mathrm{AR}(\mathrm{n}=1)$ while subgroup B2 was composed of 11 representing those obtained from BSR, MR, ESR and AR. The genotypes and cultivar of tobacco showed wide diversity, being scattered all over the dendrogram within regions and provinces. Generally, the relationships between the genotypes and cultivar on a dendrogram can be attributed to their diversity and geographical locations, but in this study, the genotypes obtained from the same location were found in different groups. This situation can be explained by the exchange of plant genetic resources among farmers within and between the provinces or regions. 
Table 3. Performance (mean values) of 29 Turkish tobacco genotypes and one cultivar in terms of six parameters.

\begin{tabular}{|c|c|c|c|c|c|c|c|c|c|c|c|c|c|}
\hline \multirow{2}{*}{ No } & \multirow{2}{*}{$\begin{array}{c}\text { Genotypes/ } \\
\text { Cultivar }\end{array}$} & \multicolumn{2}{|c|}{ DFT (day) } & \multicolumn{2}{|c|}{ DT (day) } & \multicolumn{2}{|c|}{ PH (cm) } & \multicolumn{2}{|c|}{ LL (cm) } & \multicolumn{2}{|c|}{ LW (cm) } & \multicolumn{2}{|c|}{ OV } \\
\hline & & 2015 & 2016 & 2015 & 2016 & 2015 & 2016 & 2015 & 2016 & 2015 & 2016 & 2015 & 2016 \\
\hline 1 & AR-1 & $103.00^{b-g}$ & $106.00^{\text {ght }}$ & $98.00^{\mathrm{d}-\mathrm{g}}$ & $100.67^{h i j}$ & $142.00^{\mathrm{a}}$ & $60.33^{\mathrm{a}-\mathrm{f}}$ & $16.84^{\mathrm{a}-\mathrm{d}}$ & $18.53^{\mathrm{c}-\mathrm{f}}$ & $10.87^{\mathrm{a}-\mathrm{f}}$ & $7.73^{g}$ & $1.71^{\text {efg }}$ & $2.16^{\mathrm{c}-\mathrm{g}}$ \\
\hline 2 & AR-2 & $109.00^{\mathrm{ab}}$ & $112.33^{\mathrm{c}}$ & $106.67^{\mathrm{abc}}$ & $108.33^{c}$ & $80.82^{f}$ & $51.30^{\mathrm{b}-\mathrm{f}}$ & $12.88^{\mathrm{d}}$ & $18.67^{\mathrm{c}-\mathrm{f}}$ & $7.85^{\mathrm{h} 1}$ & $7.60^{\mathrm{g}}$ & $1.88^{\mathrm{c}-\mathrm{f}}$ & $2.32^{\mathrm{bc}}$ \\
\hline 3 & MR-1 & $107.00^{\mathrm{bcd}}$ & $109.67^{\mathrm{de}}$ & $101.00^{\mathrm{b}-\mathrm{f}}$ & $103.33^{\text {ef }}$ & $124.87^{\mathrm{a}-\mathrm{d}}$ & $57.50^{\mathrm{a}-\mathrm{f}}$ & $16.54^{\mathrm{a}-\mathrm{d}}$ & $19.10^{\mathrm{c}-\mathrm{f}}$ & $10.41^{\mathrm{a}-1}$ & $11.95^{\mathrm{a}-\mathrm{f}}$ & $1.86^{\mathrm{c}-\mathrm{f}}$ & $1.57^{\mathrm{k}}$ \\
\hline 4 & ESR-1 & $108.00^{\mathrm{abc}}$ & $110.33^{\mathrm{d}}$ & $105.00^{\mathrm{a}-\mathrm{d}}$ & $107.33^{c}$ & $86.12^{\mathrm{ef}}$ & $55.60^{\mathrm{a}-\mathrm{f}}$ & $19.52^{\mathrm{abc}}$ & $28.67^{\mathrm{a}}$ & $9.69^{b-1}$ & $8.93^{\mathrm{c}-\mathrm{g}}$ & $2.53^{\mathrm{a}}$ & $2.96^{\mathrm{a}}$ \\
\hline 5 & BSR-1 & $95.00^{1 \mathrm{j}}$ & $101.33^{\mathrm{opq}}$ & $90.00^{\mathrm{gh}}$ & $96.00^{\mathrm{n}}$ & $115.67^{\mathrm{a}-\mathrm{f}}$ & $59.00^{\mathrm{a}-\mathrm{f}}$ & $13.64^{\mathrm{cd}}$ & $21.20^{\mathrm{b}-\mathrm{f}}$ & $8.60^{\mathrm{e}-1}$ & $12.10^{\mathrm{a}-\mathrm{f}}$ & $1.88^{\mathrm{c}-\mathrm{f}}$ & $1.75^{\mathrm{g}-\mathrm{k}}$ \\
\hline 6 & BSR-2 & $107.00^{\mathrm{bcd}}$ & $109.67^{\mathrm{de}}$ & $102.00^{\mathrm{b}-\mathrm{e}}$ & $104.00^{\mathrm{e}}$ & $129.15^{\mathrm{abc}}$ & $49.58^{\mathrm{ef}}$ & $21.44^{\mathrm{a}}$ & $23.83^{\mathrm{a}-\mathrm{e}}$ & $10.54^{\mathrm{a}-\mathrm{h}}$ & $8.10^{\mathrm{fg}}$ & $2.01^{\text {cde }}$ & $2.64^{\mathrm{ab}}$ \\
\hline 7 & MR-2 & $106.00^{\mathrm{b}-\mathrm{e}}$ & $108.33^{\text {ef }}$ & $101.00^{\mathrm{b}-\mathrm{f}}$ & $104.00^{\mathrm{e}}$ & $123.67^{\mathrm{a}-\mathrm{d}}$ & $77.27^{\mathrm{a}-\mathrm{f}}$ & $13.02^{\mathrm{d}}$ & $18.47^{\mathrm{c}-\mathrm{f}}$ & $7.90^{\mathrm{gh} 1}$ & $9.23^{\mathrm{b}-\mathrm{g}}$ & $1.98^{\text {cde }}$ & $1.93^{\mathrm{c}-\mathrm{k}}$ \\
\hline 8 & MR-3 & $101.00^{\mathrm{d}-1}$ & $104.67^{1 \mathrm{jk}}$ & $97.00^{\mathrm{d}-\mathrm{g}}$ & $100.33^{\mathrm{ij}}$ & $118.13^{\mathrm{a}-\mathrm{e}}$ & $50.88^{\mathrm{c}-\mathrm{f}}$ & $14.01^{\mathrm{cd}}$ & $24.55^{\mathrm{a}-\mathrm{d}}$ & $8.32^{\mathrm{f}-1}$ & $11.07^{\mathrm{a}-\mathrm{g}}$ & $2.02^{\mathrm{b}-\mathrm{e}}$ & $2.15^{\mathrm{c}-\mathrm{h}}$ \\
\hline 9 & ESR-2 & $99.67^{\mathrm{e}-1}$ & $102.67^{\mathrm{mno}}$ & $97.00^{\mathrm{d}-\mathrm{g}}$ & $98.00^{1}$ & $116.47^{\mathrm{a}-\mathrm{f}}$ & $77.89^{\mathrm{a}-\mathrm{f}}$ & $17.21^{\mathrm{a}-\mathrm{d}}$ & $24.80^{\mathrm{a}-\mathrm{d}}$ & $11.56^{\mathrm{a}-\mathrm{d}}$ & $13.20^{\mathrm{ab}}$ & $1.75^{\mathrm{efg}}$ & $1.73^{\mathrm{h}-\mathrm{k}}$ \\
\hline 10 & ESR-3 & $101.00^{\mathrm{d}-1}$ & $103.67^{\mathrm{klm}}$ & $96.67^{\mathrm{efg}}$ & $101.00^{h i j}$ & $111.30^{\mathrm{a}-\mathrm{f}}$ & $66.44^{\mathrm{a}-\mathrm{f}}$ & $17.73^{\mathrm{a}-\mathrm{d}}$ & $21.80^{\mathrm{a}-\mathrm{f}}$ & $11.79^{\mathrm{abc}}$ & $12.80^{\mathrm{abc}}$ & $1.76^{\mathrm{efg}}$ & $1.81^{\mathrm{f}-\mathrm{k}}$ \\
\hline 11 & MR-4 & $108.00^{\mathrm{abc}}$ & $109.67^{\mathrm{de}}$ & $102.00^{\mathrm{b}-\mathrm{e}}$ & $103.00^{\mathrm{ef}}$ & $131.53^{\mathrm{abc}}$ & $88.00^{\mathrm{a}-\mathrm{e}}$ & $15.84^{\mathrm{a}-\mathrm{d}}$ & $19.60^{\mathrm{b}-\mathrm{f}}$ & $10.74^{\mathrm{a}-\mathrm{f}}$ & $10.27^{\mathrm{c}-\mathrm{g}}$ & $1.61^{\mathrm{fg}}$ & $1.83^{\mathrm{e}-\mathrm{k}}$ \\
\hline 12 & MR-5 & $102.00^{\mathrm{c}-\mathrm{h}}$ & $104.67^{1 \mathrm{jk}}$ & $97.00^{\mathrm{d}-\mathrm{g}}$ & $98.33^{\mathrm{kl}}$ & $129.67^{\mathrm{abc}}$ & $91.28^{\mathrm{ab}}$ & $16.32^{\mathrm{a}-\mathrm{d}}$ & $24.73^{\mathrm{a}-\mathrm{d}}$ & $12.29^{\mathrm{ab}}$ & $14.00^{\mathrm{a}}$ & $1.47^{\mathrm{g}}$ & $1.78^{\mathrm{g}-\mathrm{k}}$ \\
\hline 13 & ESR-4 & $92.00^{\mathrm{j}}$ & $97.33^{\mathrm{s}}$ & $88.00^{\mathrm{h}}$ & $96.33^{\mathrm{mn}}$ & $100.13^{\mathrm{c}-\mathrm{f}}$ & $76.30^{\mathrm{a}-\mathrm{f}}$ & $19.77^{\mathrm{abc}}$ & $25.53^{\mathrm{abc}}$ & $12.26^{\mathrm{ab}}$ & $11.50^{\mathrm{a}-\mathrm{g}}$ & $1.80^{\mathrm{d}-\mathrm{g}}$ & $2.18^{\mathrm{c}-\mathrm{g}}$ \\
\hline 14 & ESR-5 & $97.00^{\mathrm{g}-\mathrm{j}}$ & $103.00^{\operatorname{lmn}}$ & $93.00^{\text {fgh }}$ & $98.33^{\mathrm{kl}}$ & $108.60^{\mathrm{a}-\mathrm{f}}$ & $55.17^{\mathrm{a}-\mathrm{f}}$ & $18.07^{\mathrm{a}-\mathrm{d}}$ & $23.03^{\mathrm{a}-\mathrm{f}}$ & $11.28^{\mathrm{a}-\mathrm{e}}$ & $10.60^{\mathrm{b}-\mathrm{g}}$ & $1.78^{\mathrm{d}-\mathrm{g}}$ & $2.14^{\mathrm{c}-1}$ \\
\hline 15 & ESR-6 & $103.00^{\mathrm{b}-\mathrm{g}}$ & $105.33^{\mathrm{hij}}$ & $99.00^{c-f}$ & $100.67^{\text {hij }}$ & $106.27^{\mathrm{a}-\mathrm{f}}$ & $43.17^{\mathrm{f}}$ & $19.26^{\mathrm{abc}}$ & $24.83^{\mathrm{a}-\mathrm{d}}$ & $10.59^{\mathrm{a}-\mathrm{g}}$ & $8.37^{\mathrm{d}-\mathrm{g}}$ & $2.20^{\mathrm{abc}}$ & $2.88^{\mathrm{a}}$ \\
\hline 16 & ESR-7 & $104.00^{\mathrm{b}-\mathrm{f}}$ & $106.33^{\mathrm{gh}}$ & $99.00^{\mathrm{c}-\mathrm{f}}$ & $102.00^{\mathrm{fgh}}$ & $112.40^{\mathrm{a}-\mathrm{f}}$ & $90.20^{\mathrm{a}-\mathrm{d}}$ & $20.9^{\mathrm{ab}}$ & $24.30^{\mathrm{a}-\mathrm{d}}$ & $10.80^{\mathrm{a}-\mathrm{f}}$ & $12.25^{\mathrm{a}-\mathrm{d}}$ & $1.87^{\mathrm{c}-\mathrm{f}}$ & $2.28^{\mathrm{bcd}}$ \\
\hline 17 & ESR-8 & $114.67^{\mathrm{a}}$ & $116.66^{\mathrm{a}}$ & $109.00^{\mathrm{ab}}$ & $111.33^{b}$ & $115.47^{\mathrm{a}-\mathrm{f}}$ & $92.00^{\mathrm{a}}$ & $15.65^{\mathrm{a}-\mathrm{d}}$ & $23.50^{\mathrm{a}-\mathrm{e}}$ & $10.44^{\mathrm{a}-\mathrm{h}}$ & $12.55^{\mathrm{abc}}$ & $1.72^{\mathrm{efg}}$ & $1.86^{\mathrm{d}-\mathrm{k}}$ \\
\hline 18 & ESR-9 & $101.00^{\mathrm{d}-1}$ & $104.33^{\mathrm{jkl}}$ & $97.00^{\mathrm{d}-\mathrm{g}}$ & $101.33^{\text {ght }}$ & $112.99^{\mathrm{a}-\mathrm{f}}$ & $69.00^{\mathrm{a}-\mathrm{f}}$ & $16.47^{\mathrm{a}-\mathrm{d}}$ & $23.20^{\mathrm{a}-\mathrm{f}}$ & $10.94^{\mathrm{a}-\mathrm{f}}$ & $13.50^{\mathrm{a}}$ & $1.76^{\mathrm{efg}}$ & $1.75^{\mathrm{g}-\mathrm{k}}$ \\
\hline 19 & AR-3 & $103.00^{\mathrm{b}-\mathrm{g}}$ & $104.33^{\mathrm{jkl}}$ & $100.00^{\mathrm{c}-\mathrm{f}}$ & $102.67^{\mathrm{efg}}$ & $109.67^{\mathrm{a}-\mathrm{f}}$ & $50.11^{\text {def }}$ & $13.01^{\mathrm{d}}$ & $17.90^{\mathrm{def}}$ & $7.86^{\mathrm{h} 1}$ & $8.50^{\mathrm{d}-\mathrm{g}}$ & $1.97^{\text {cde }}$ & $2.02^{\mathrm{c}-\mathrm{j}}$ \\
\hline 20 & ESR-10 & $95.00^{\mathrm{ij}}$ & $99.00^{r}$ & $95.00^{\mathrm{e}-\mathrm{h}}$ & $103.67^{\mathrm{e}}$ & $105.62^{\mathrm{a}-\mathrm{f}}$ & $90.77^{\mathrm{abc}}$ & $19.41^{\mathrm{abc}}$ & $21.60^{\mathrm{a}-\mathrm{f}}$ & $12.58^{\mathrm{a}}$ & $12.20^{\mathrm{a}-\mathrm{e}}$ & $1.83^{\mathrm{def}}$ & $1.72^{1 \mathrm{jk}}$ \\
\hline 21 & AR-4 & $114.00^{\mathrm{a}}$ & $114.00^{\mathrm{b}}$ & $111.00^{\mathrm{a}}$ & $113.67^{\mathrm{a}}$ & $111.40^{\mathrm{a}-\mathrm{f}}$ & $57.65^{\mathrm{a}-\mathrm{f}}$ & $12.78^{\mathrm{d}}$ & $16.80^{\mathrm{ef}}$ & $8.32^{\mathrm{f}-1}$ & $8.85^{\mathrm{c}-\mathrm{g}}$ & $1.85^{\mathrm{c}-\mathrm{f}}$ & $1.83^{\mathrm{e}-\mathrm{k}}$ \\
\hline 22 & BSR-3 & $99.00^{\mathrm{f}-1}$ & $102.33^{\mathrm{m}-\mathrm{p}}$ & $96.00^{\mathrm{e}-\mathrm{h}}$ & $99.67^{\mathrm{jk}}$ & $138.63^{\mathrm{ab}}$ & $93.51^{\mathrm{a}}$ & $16.34^{\mathrm{a}-\mathrm{d}}$ & $26.67^{\mathrm{ab}}$ & $9.28^{\mathrm{c}-1}$ & $13.43^{\mathrm{a}}$ & $2.12^{\mathrm{bcd}}$ & $1.84^{\mathrm{e}-\mathrm{k}}$ \\
\hline 23 & BSR-4 & $97.00^{g-j}$ & $100.67^{q}$ & $93.00^{\text {fgh }}$ & $96.33^{\mathrm{mn}}$ & $120.71^{\mathrm{a}-\mathrm{e}}$ & $70.35^{\mathrm{a}-\mathrm{f}}$ & $15.03^{\text {bcd }}$ & $22.70^{\mathrm{a}-\mathrm{f}}$ & $8.99^{\mathrm{d}-1}$ & $10.48^{\mathrm{a}-\mathrm{g}}$ & $1.94^{\mathrm{c}-\mathrm{f}}$ & $2.25^{\mathrm{b}-\mathrm{e}}$ \\
\hline 24 & BSR-5 & $96.00^{\text {hij }}$ & $101.67^{\mathrm{n}-\mathrm{q}}$ & $93.00^{\mathrm{fgh}}$ & $95.00^{\mathrm{n}}$ & $103.71^{b-f}$ & $60.13^{\mathrm{a}-\mathrm{f}}$ & $15.42^{\mathrm{a}-\mathrm{d}}$ & $21.50^{\mathrm{a}-\mathrm{f}}$ & $10.71^{\mathrm{a}-\mathrm{f}}$ & $11.83^{\mathrm{a}-\mathrm{f}}$ & $1.71^{\mathrm{efg}}$ & $1.83^{\mathrm{e}-\mathrm{k}}$ \\
\hline 25 & BSR-6 & $96.00^{\text {hij }}$ & $101.00^{\mathrm{pq}}$ & $93.00^{\text {fgh }}$ & $97.67^{\mathrm{lm}}$ & $104.33^{\mathrm{b}-\mathrm{f}}$ & $64.33^{\mathrm{a}-\mathrm{f}}$ & $15.80^{\mathrm{a}-\mathrm{d}}$ & $20.73^{b-f}$ & $10.33^{\mathrm{a}-1}$ & $10.03^{\mathrm{a}-\mathrm{g}}$ & $1.80^{\mathrm{d}-\mathrm{g}}$ & $2.02^{\mathrm{c}-\mathrm{j}}$ \\
\hline 26 & BSR-7 & $100.00^{\mathrm{e}-1}$ & $102.33^{\mathrm{m}-\mathrm{p}}$ & $97.00^{\mathrm{d}-\mathrm{g}}$ & $101.00^{\text {hij }}$ & $128.13^{\mathrm{abc}}$ & $91.00^{\mathrm{abc}}$ & $15.19^{\mathrm{bcd}}$ & $15.90^{\mathrm{f}}$ & $8.75^{\mathrm{e}-1}$ & $9.20^{\mathrm{b}-\mathrm{g}}$ & $2.03^{\mathrm{b}-\mathrm{e}}$ & $1.66^{\mathrm{jk}}$ \\
\hline 27 & BSR-8 & $98.67^{\mathrm{f}-\mathrm{j}}$ & $102.00^{\mathrm{n}-\mathrm{q}}$ & $99.00^{\mathrm{c}-\mathrm{f}}$ & $102.00^{\mathrm{fgh}}$ & $131.87^{\mathrm{abc}}$ & $55.53^{\mathrm{a}-\mathrm{f}}$ & $15.78^{\mathrm{a}-\mathrm{d}}$ & $19.52^{b-f}$ & $9.42^{\mathrm{c}-1}$ & $9.17^{\mathrm{c}-\mathrm{g}}$ & $1.97^{\text {cde }}$ & $1.98^{\mathrm{c}-\mathrm{k}}$ \\
\hline 28 & BSR-9 & $103.00^{\mathrm{b}-\mathrm{g}}$ & $105.67^{\mathrm{hij}}$ & $100.00^{\mathrm{c}-\mathrm{f}}$ & $103.33^{\mathrm{ef}}$ & $97.65^{\mathrm{c}-\mathrm{f}}$ & $59.13^{\mathrm{a}-\mathrm{f}}$ & $18.03^{\mathrm{a}-\mathrm{d}}$ & $19.00^{\mathrm{c}-\mathrm{f}}$ & $7.71^{1}$ & $8.20^{\text {efg }}$ & $2.36^{\mathrm{ab}}$ & $2.21^{\mathrm{c}-\mathrm{f}}$ \\
\hline 29 & BSR-10 & $101.00^{\mathrm{d}-1}$ & $106.33^{\mathrm{gh}}$ & $98.00^{\mathrm{d}-\mathrm{g}}$ & $105.67^{\mathrm{d}}$ & $120.13^{\mathrm{a}-\mathrm{e}}$ & $65.92^{\mathrm{a}-\mathrm{f}}$ & $13.96^{\mathrm{cd}}$ & $21.43^{\mathrm{a}-\mathrm{f}}$ & $9.38^{\mathrm{c}-1}$ & $10.63^{\mathrm{a}-\mathrm{g}}$ & $2.02^{\text {cde }}$ & $2.17^{\mathrm{c}-\mathrm{g}}$ \\
\hline 30 & ESR-11 & $105.00^{\mathrm{b}-\mathrm{f}}$ & $107.33^{\mathrm{fg}}$ & $101.00^{\mathrm{b}-\mathrm{f}}$ & $103.67^{\mathrm{e}}$ & $89.67^{\text {def }}$ & $62.67^{\mathrm{a}-\mathrm{f}}$ & $16.79^{\mathrm{a}-\mathrm{d}}$ & $22.30^{\mathrm{a}-\mathrm{f}}$ & $9.58^{\mathrm{b}-1}$ & $10.57^{\mathrm{a}-\mathrm{g}}$ & $2.13^{\mathrm{bcd}}$ & $2.05^{\mathrm{c}-\mathrm{j}}$ \\
\hline & Average & 102.20 & 105.42 & 98.48 & 101.96 & 114.23 & 67.73 & 16.42 & 21.81 & 9.99 & 10.63 & 1.91 & 2.04 \\
\hline & $\mathrm{CV} \%$ & 3.05 & 2.18 & 3.89 & 1.95 & 14.85 & 27.26 & 17.41 & 15.59 & 12.49 & 17.40 & 8.28 & 9.63 \\
\hline & $\operatorname{LSD}(1 \%)$ & 2.14 & 1.58 & 2.61 & 1.37 & 36.89 & 40.15 & 6.22 & 7.40 & 2.71 & 4.02 & 0.35 & 0.43 \\
\hline
\end{tabular}

DFT: Days to Flowering Time, DT: Days to Topping, PH: Plant Height, LL: Leaf Length, LW: Leaf Width, OV: Ovality Value 
Table 4. General average of tobacco regions.

\begin{tabular}{|c|c|c|c|c|c|c|c|c|c|c|c|c|}
\hline \multirow{2}{*}{$\begin{array}{l}\text { Tobacco } \\
\text { Regions }\end{array}$} & \multicolumn{2}{|c|}{ DFT (day) } & \multicolumn{2}{|c|}{ DT (day) } & \multicolumn{2}{|c|}{ PH (cm) } & \multicolumn{2}{|c|}{ LL (cm) } & \multicolumn{2}{|c|}{ LW (cm) } & \multicolumn{2}{|c|}{ OV } \\
\hline & 2015 & 2016 & 2015 & 2016 & 2015 & 2016 & 2015 & 2016 & 2015 & 2016 & 2015 & 2016 \\
\hline $\mathrm{AR}$ & $107.25^{\mathrm{a}}$ & $109.17^{\mathrm{a}}$ & $103.92^{\mathrm{a}}$ & $106.33^{\mathrm{a}}$ & $110.97^{\mathrm{ab}}$ & 63.50 & $13.88^{b}$ & $17.98^{b}$ & $8.72^{\mathrm{c}}$ & $8.17^{b}$ & $1.86^{\mathrm{bc}}$ & $2.09^{\mathrm{a}}$ \\
\hline BSR & $99.27^{\mathrm{c}}$ & $103.30^{\mathrm{b}}$ & $96.10^{\mathrm{b}}$ & $100.07^{\mathrm{b}}$ & $119.76^{\mathrm{ab}}$ & 66.65 & $15.83^{\mathrm{ab}}$ & $21.25^{\mathrm{ab}}$ & $9.37^{\mathrm{bc}}$ & $10.32^{\mathrm{ab}}$ & $1.97^{\mathrm{a}}$ & $2.03^{\mathrm{a}}$ \\
\hline ESR & $101.85^{\mathrm{bc}}$ & $105.09^{b}$ & $98.15^{\mathrm{b}}$ & $102.15^{b}$ & $105.91^{\mathrm{b}}$ & 67.84 & $18.36^{\mathrm{a}}$ & $23.96^{\mathrm{a}}$ & $11.05^{\mathrm{a}}$ & $11.50^{\mathrm{a}}$ & $1.92^{\mathrm{ab}}$ & $2.12^{\mathrm{a}}$ \\
\hline MR & $104.80^{\mathrm{ab}}$ & $107.40^{\mathrm{a}}$ & $99.60^{\mathrm{ab}}$ & $101.80^{\mathrm{b}}$ & $125.57^{\mathrm{a}}$ & 73.12 & $15.15^{\mathrm{b}}$ & $21.29^{\mathrm{ab}}$ & $9.93^{\mathrm{ab}}$ & $11.30^{\mathrm{a}}$ & $1.79^{c}$ & $1.85^{\mathrm{b}}$ \\
\hline Average & 103.29 & 106.24 & 99.44 & 102.59 & 115.55 & 67.78 & 15.8 & 21.12 & 9.77 & 10.32 & 1.88 & 2.02 \\
\hline $\operatorname{LSD}(1 \%)$ & 3.35 & 2.30 & 5.40 & 2.97 & 16.24 & 21.07 & 3.12 & 3.35 & 1.19 & 2.41 & 0.10 & 0.18 \\
\hline $\mathrm{CV} \%$ & 1.07 & 0.72 & 1.79 & 0.96 & 4.64 & 10.27 & 6.53 & 5.24 & 4.03 & 7.73 & 1.72 & 2.86 \\
\hline
\end{tabular}

AR: Aegean Region; BSR: Black Sea Region; ESR: Eastern South Region; MR: Marmara Region 
Table 5. Mean values of yield of tobacco cultivar and genotypes used in the study.

\begin{tabular}{|c|c|c|c|c|c|c|c|}
\hline \multirow{2}{*}{ No } & \multirow{2}{*}{ Genotypes/Cultivar } & \multicolumn{2}{|c|}{ NL (number) } & \multicolumn{2}{|c|}{ FLW $\left(\mathrm{kg} \mathrm{da}^{-1}\right)$} & \multicolumn{2}{|c|}{ DLW $\left(\mathrm{kg} \mathrm{da}^{-1}\right)$} \\
\hline & & 2015 & 2016 & 2015 & 2016 & 2015 & 2016 \\
\hline 1 & AR-1 & $28.20^{\mathrm{ab}}$ & $15.30^{b}$ & $525.00^{\mathrm{b}}$ & $95.00^{\mathrm{d}}$ & $119.74^{\mathrm{a}}$ & $27.49^{\mathrm{cd}}$ \\
\hline 2 & AR-2 & $22.27^{\mathrm{b}-\mathrm{f}}$ & $13.56^{\mathrm{b}}$ & $403.30^{\mathrm{c}-\mathrm{f}}$ & $144.11^{\mathrm{bcd}}$ & $74.42^{\mathrm{bc}}$ & $31.85^{\mathrm{cd}}$ \\
\hline 3 & MR-1 & $21.60^{\mathrm{b}-\mathrm{f}}$ & $15.17^{\mathrm{b}}$ & $277.60^{\mathrm{g}-\mathrm{j}}$ & $100.67^{\mathrm{d}}$ & $63.67^{\mathrm{bc}}$ & $41.50^{\mathrm{a}-\mathrm{d}}$ \\
\hline 4 & ESR-1 & $21.47^{\mathrm{b}-\mathrm{f}}$ & $13.65^{\mathrm{b}}$ & $240.00^{\mathrm{jk}}$ & $156.78^{\mathrm{bcd}}$ & $49.60^{c}$ & $31.97^{\mathrm{cd}}$ \\
\hline 5 & BSR-1 & $22.60^{\mathrm{b}-\mathrm{e}}$ & $16.53^{\mathrm{b}}$ & $351.30^{\mathrm{d}-1}$ & $191.56^{\mathrm{a}-\mathrm{d}}$ & $67.07^{\mathrm{bc}}$ & $35.22^{\mathrm{cd}}$ \\
\hline 6 & BSR-2 & $31.20^{\mathrm{a}}$ & $12.17^{\mathrm{b}}$ & $371.30^{\mathrm{c}-1}$ & $190.00^{\mathrm{a}-\mathrm{d}}$ & $68.97^{\mathrm{bc}}$ & $49.97^{\mathrm{abc}}$ \\
\hline 7 & MR-2 & $20.73^{\mathrm{c}-\mathrm{g}}$ & $11.75^{\mathrm{b}}$ & $365.00^{\mathrm{c}-1}$ & $309.11^{\mathrm{ab}}$ & $65.11^{\mathrm{bc}}$ & $31.55^{\mathrm{cd}}$ \\
\hline 8 & MR-3 & $20.49^{\mathrm{c}-\mathrm{g}}$ & $14.70^{\mathrm{b}}$ & $318.80^{\mathrm{e}-\mathrm{j}}$ & $182.85^{\mathrm{a}-\mathrm{d}}$ & $79.94^{\mathrm{bc}}$ & $35.43^{\mathrm{cd}}$ \\
\hline 9 & ESR-2 & $21.47^{\mathrm{b}-\mathrm{f}}$ & $15.75^{\mathrm{b}}$ & $395.00^{\mathrm{c}-\mathrm{f}}$ & $215.00^{\mathrm{a}-\mathrm{d}}$ & $99.87^{\mathrm{ab}}$ & $37.77^{\mathrm{bcd}}$ \\
\hline 10 & ESR-3 & $19.13^{\mathrm{d}-\mathrm{g}}$ & $10.33^{\mathrm{b}}$ & $416.30^{\mathrm{b}-\mathrm{e}}$ & $162.14^{\mathrm{a}-\mathrm{d}}$ & $80.74^{b c}$ & $24.64^{\mathrm{d}}$ \\
\hline 11 & MR-4 & $13.67^{\mathrm{g}}$ & $11.12^{\mathrm{b}}$ & $467.50^{\mathrm{bc}}$ & $138.13^{\mathrm{bcd}}$ & $75.02^{\mathrm{bc}}$ & $27.59^{\mathrm{cd}}$ \\
\hline 12 & MR-5 & $16.00^{\mathrm{efg}}$ & $14.33^{\mathrm{b}}$ & $158.80^{\mathrm{k}}$ & $228.72^{\mathrm{a}-\mathrm{d}}$ & $73.68^{\mathrm{bc}}$ & $37.14^{\mathrm{cd}}$ \\
\hline 13 & ESR-4 & $14.93^{\mathrm{fg}}$ & $10.47^{\mathrm{b}}$ & $380.00^{\mathrm{c}-\mathrm{g}}$ & $106.72^{\mathrm{d}}$ & $65.43^{\mathrm{bc}}$ & $22.85^{\mathrm{d}}$ \\
\hline 14 & ESR-5 & $17.87^{\mathrm{d}-\mathrm{g}}$ & $11.27^{\mathrm{b}}$ & $368.80^{c-1}$ & $178.56^{\mathrm{ab}}$ & $81.14^{\mathrm{abc}}$ & $39.37^{\mathrm{a}-\mathrm{d}}$ \\
\hline 15 & ESR-6 & $18.88^{\mathrm{d}-\mathrm{g}}$ & $13.89^{\mathrm{b}}$ & $267.50^{\mathrm{h}-\mathrm{k}}$ & $320.19^{\mathrm{ab}}$ & $77.07^{\mathrm{bc}}$ & $47.08^{\mathrm{a}-\mathrm{d}}$ \\
\hline 16 & ESR-7 & $22.27^{b-f}$ & $14.60^{\mathrm{b}}$ & $646.30^{\mathrm{a}}$ & $161.11^{\mathrm{bcd}}$ & $83.24^{\mathrm{abc}}$ & $28.12^{\mathrm{cd}}$ \\
\hline 17 & ESR-8 & $17.93^{\mathrm{d}-\mathrm{g}}$ & $15.75^{\mathrm{b}}$ & $435.00^{\mathrm{bcd}}$ & $305.00^{\mathrm{abc}}$ & $77.85^{\mathrm{bc}}$ & $62.87^{\mathrm{ab}}$ \\
\hline 18 & ESR-9 & $17.93^{\mathrm{d}-\mathrm{g}}$ & $12.00^{\mathrm{b}}$ & $426.30^{\mathrm{b}-\mathrm{e}}$ & $175.00^{\mathrm{a}-\mathrm{d}}$ & $89.60^{\mathrm{ab}}$ & $30.91^{\mathrm{cd}}$ \\
\hline 19 & AR-3 & $18.07^{\mathrm{d}-\mathrm{g}}$ & $10.90^{\mathrm{b}}$ & $443.80^{\mathrm{bcd}}$ & $112.00^{\mathrm{cd}}$ & $75.73^{\mathrm{bc}}$ & $21.85^{\mathrm{d}}$ \\
\hline 20 & ESR-10 & $20.93^{\mathrm{b}-\mathrm{g}}$ & $13.75^{\mathrm{b}}$ & $450.00^{\mathrm{bcd}}$ & $198.39^{\mathrm{a}-\mathrm{d}}$ & $95.06^{\mathrm{ab}}$ & $31.15^{\mathrm{cd}}$ \\
\hline 21 & AR-4 & $22.07^{\mathrm{b}-\mathrm{f}}$ & $15.00^{\mathrm{b}}$ & $218.80^{\mathrm{jk}}$ & $176.22^{\mathrm{a}-\mathrm{d}}$ & $72.10^{\text {bc }}$ & $47.13^{\mathrm{a}-\mathrm{d}}$ \\
\hline 22 & BSR-3 & $21.20^{\mathrm{b}-\mathrm{f}}$ & $11.83^{\mathrm{b}}$ & $266.30 \mathrm{r}^{\mathrm{jk}}$ & $358.22^{\mathrm{a}}$ & $65.06^{\mathrm{bc}}$ & $24.96^{\mathrm{cd}}$ \\
\hline 23 & BSR-4 & $24.27^{\mathrm{a}-\mathrm{d}}$ & $31.89^{\mathrm{a}}$ & $306.30^{f-j}$ & $276.07^{\mathrm{a}-\mathrm{d}}$ & $68.36^{\mathrm{bc}}$ & $68.87^{\mathrm{a}}$ \\
\hline 24 & BSR-5 & $30.47^{\mathrm{a}}$ & $17.50^{\mathrm{b}}$ & $396.30^{\mathrm{c}-\mathrm{f}}$ & $251.67^{\mathrm{a}-\mathrm{d}}$ & $95.48^{\mathrm{ab}}$ & $36.93^{\mathrm{cd}}$ \\
\hline 25 & BSR-6 & $22.87^{\mathrm{b}-\mathrm{e}}$ & $13.30^{\mathrm{b}}$ & $425.00^{\mathrm{b}-\mathrm{e}}$ & $137.67^{\mathrm{bcd}}$ & $94.42^{\mathrm{ab}}$ & $22.37^{\mathrm{d}}$ \\
\hline 26 & BSR-7 & $19.73^{\mathrm{d}-\mathrm{g}}$ & $14.11^{\mathrm{b}}$ & $376.30^{\mathrm{c}-\mathrm{h}}$ & $285.93^{\mathrm{a}-\mathrm{d}}$ & $96.61^{\mathrm{ab}}$ & $45.06^{\mathrm{a}-\mathrm{d}}$ \\
\hline 27 & BSR-8 & $27.40^{\mathrm{abc}}$ & $12.00^{\mathrm{b}}$ & $297.50^{f-j}$ & $163.11^{\mathrm{a}-\mathrm{d}}$ & $81.63^{\mathrm{abc}}$ & $34.01^{\mathrm{cd}}$ \\
\hline 28 & BSR-9 & $21.33^{\mathrm{b}-\mathrm{f}}$ & $12.87^{\mathrm{b}}$ & $262.50 \mathrm{1}^{\mathrm{jk}}$ & $90.11^{\mathrm{d}}$ & $64.28^{\mathrm{bc}}$ & $22.39^{\mathrm{d}}$ \\
\hline 29 & BSR-10 & $20.53^{\mathrm{c}-\mathrm{g}}$ & $19.00^{\mathrm{b}}$ & $383.80^{\mathrm{c}-\mathrm{g}}$ & $98.89^{\mathrm{d}}$ & $61.40^{\mathrm{bc}}$ & $27.19^{\text {cd }}$ \\
\hline 30 & ESR-11 & $19.70^{\mathrm{d}-\mathrm{g}}$ & $14.75^{\mathrm{b}}$ & $280.40^{\mathrm{bcd}}$ & $135.97^{\mathrm{bcd}}$ & $49.52^{\mathrm{c}}$ & $30.14^{\mathrm{cd}}$ \\
\hline & Average & 21.24 & 14.31 & 364.00 & 188.16 & 76.96 & 35.01 \\
\hline & CV \% & 16.13 & 37.14 & 33.83 & 48.02 & 23.14 & 33.27 \\
\hline & LSD (1\%) & 7.45 & 11.56 & 284.80 & 196.50 & 38.73 & 25.33 \\
\hline
\end{tabular}

NL: Number of Leaves, FLW: Fresh Leaf Weight, DLW: Dry Leaf Weight

Table 6. General average of tobacco regions for NL, FLW and DLW.

\begin{tabular}{lcccccc}
\hline \multirow{2}{*}{ Tobacco Regions } & \multicolumn{2}{c}{ NL (number) } & \multicolumn{2}{c}{ FLW $\left(\mathbf{k g ~ d a}^{\mathbf{- 1}}\right)$} & \multicolumn{2}{c}{ DLW $\left(\mathbf{k g ~ d a}^{-\mathbf{1}}\right)$} \\
\cline { 2 - 7 } & $\mathbf{2 0 1 5}$ & $\mathbf{2 0 1 6}$ & $\mathbf{2 0 1 5}$ & $\mathbf{2 0 1 6}$ & $\mathbf{2 0 1 5}$ & $\mathbf{2 0 1 6}$ \\
\hline AR & $23.38^{\mathrm{a}}$ & 14.42 & 392.73 & $124.14^{\mathrm{b}}$ & 76.86 & 33.20 \\
BSR & $22.98^{\mathrm{ab}}$ & 16.22 & 362.96 & $197.39^{\mathrm{ab}}$ & 74.88 & 35.41 \\
ESR & $17.86^{\mathrm{b}}$ & 12.58 & 409.11 & $189.63^{\mathrm{ab}}$ & 79.23 & 33.96 \\
MR & $23.30^{\mathrm{a}}$ & 14.18 & 383.00 & $217.70^{\mathrm{a}}$ & 76.19 & 37.99 \\
\hline Average & 21.88 & 14.35 & 386.95 & 182.22 & 76.79 & 35.14 \\
LSD (1\%) & 5.15 & 6.81 & 122.33 & 86.62 & 24.03 & 20.24 \\
CV \% & 7.77 & 15.66 & 10.44 & 15.70 & 10.34 & 19.02 \\
\hline
\end{tabular}

AR: Aegean Region; BSR: Black Sea Region; ESR: Eastern South Region; MR: Marmara Region 
Table 7. Correlation analysis of morphological traits and yield components of tobacco genotypes and cultivar.

\begin{tabular}{|c|c|c|c|c|c|c|c|c|c|}
\hline & DFT & DT & PH & NL & LL & LW & OV & FLW & DLW \\
\hline DFT & 1 & $0,927^{* *}$ & $-0,093$ & $-0,031$ & $-0,192$ & $-0,346$ & 0,161 & 0,033 & $-0,178$ \\
\hline DT & & 1 & $-0,144$ & $-0,109$ & $-0,24$ & $-0,41^{*}$ & 0,204 & $-0,077$ & $-0,335$ \\
\hline PH & & & 1 & $0,381^{*}$ & $-0,005$ & $0,441^{*}$ & $-0,548^{* *}$ & $0,432^{*}$ & $0,385^{*}$ \\
\hline NL & & & & 1 & $-0,208$ & $-0,27$ & 0,045 & 0,032 & $0,416^{*}$ \\
\hline $\mathbf{L L}$ & & & & & 1 & $0,52^{* *}$ & $0,406^{*}$ & $0,405^{*}$ & 0,17 \\
\hline LW & & & & & & 1 & $-0,532^{* *}$ & $0,423^{*}$ & $0,368^{*}$ \\
\hline OV & & & & & & & 1 & $-0,06$ & $-0,236$ \\
\hline FLW & & & & & & & & 1 & $0,512^{* *}$ \\
\hline DLW & & & & & & & & & 1 \\
\hline
\end{tabular}

${ }^{*}=\mathrm{P} \geq 0.05,{ }^{* *}=\mathrm{P} \geq 0.01$

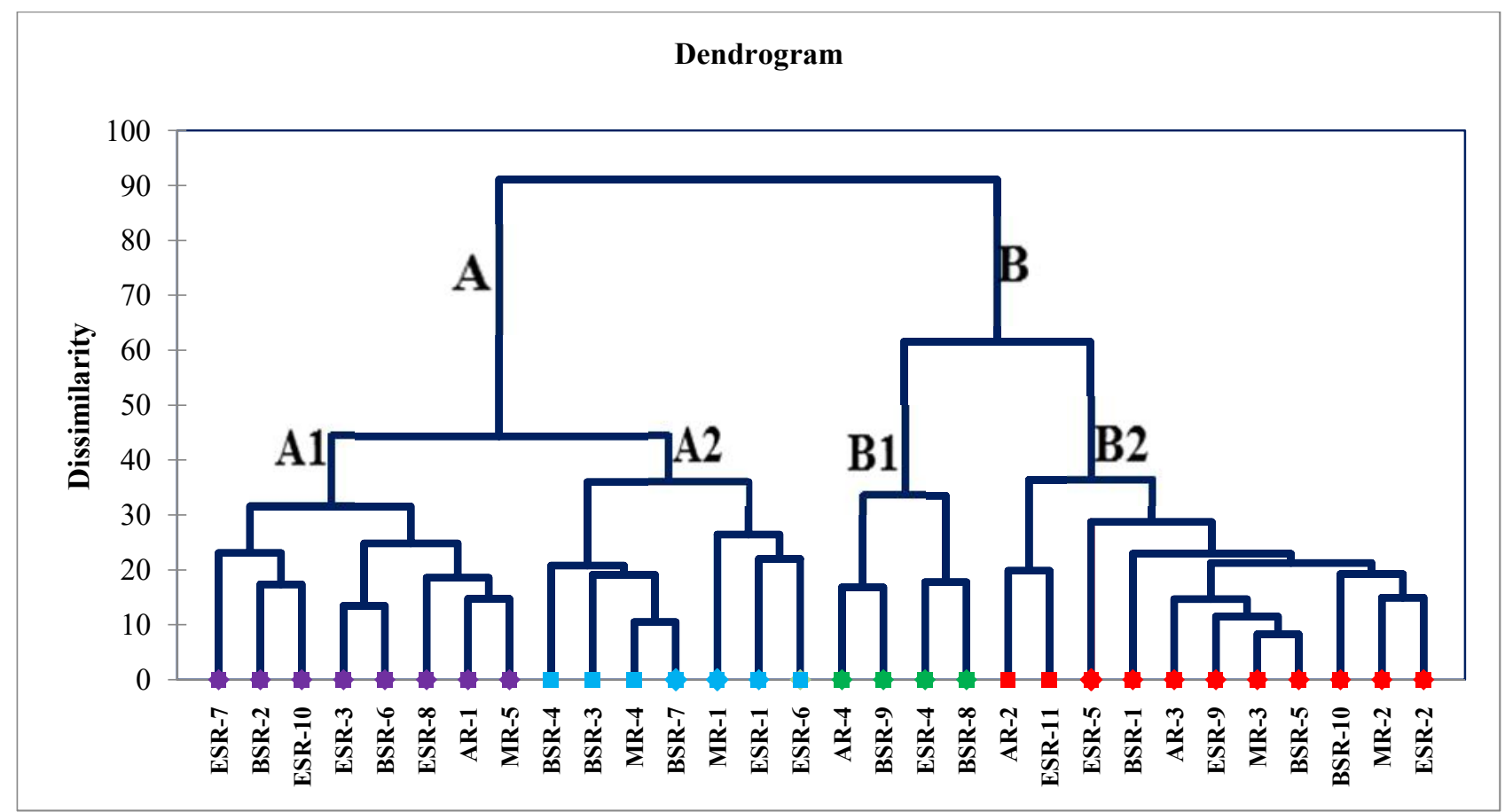

Figure 1. Dendrogram of tobacco cultivar and genotypes obtained from cluster analysis.

Conclusions: The results of this experiment showed variations among the tobacco cultivar and genotypes for yield and important morphological traits. These traits were also observed to have an impact on yield properties and ecological conditions among the tobacco genotypes. The dendrogram divided the samples to two groups (A and B). Both Group A and B contained 15 tobaccos. We concluded that three properties as LL, LW and OV could be used as good criteria for selection in the tobacco cultivar and genotypes, because these properties had high GCV, heritability and GA as percent of the mean. Considering all the data obtained from this study, of the investigated sample, the AR-1 cultivar and the MR-5, BSR-3 and BSR-4 genotypes could be recommended for breeding programs due to their high NL, FLW and DLW. We consider that the results presented in this paper will contribute to researchers, breeders and farmers both in
Turkey and other countries concerning future work regarding the Turkish tobacco genotypes.

Acknowledgements: This study is part of a MSc Thesis and we would like to thank to the Aegean Agricultural Research Institute, İzmir/Turkey for supplying seeds of some tobacco populations and we are also grateful to the Scientific Research Unit of Bolu Abant İzzet Baysal University (BAP- 2016.10.07.1090) for financial support for this study.

\section{REFERENCES}

AARI. (2002). Aegean Agricultural Research Institute. Farmer Brochure, No:89, İzmir-Turkey.

BDFA. (2015). Data of Bolu Directorate of Provincial Agriculture and Forestry. 
Burun, B and U. Emiroglu (1988). Interspecific hybridizations in Nicotiana genus. Ege University, J. The Faculty of Agriculture, 287300.

Camas, N., H. Karaali and H. Özcan (2007). The effects of different fertilizer doses on yield, quality and technological characteristics of tobacco genotype in Erbaa-Taşova conditions. TTL Foreign Trade. A.Ş.'s Research Result Report of 2007 year.

Deshmukh, S. N., M. S. Basu and P. S. Reddy (1986). Genetic variability, character association and path analysis of quantitative traits in Virginia bunch varieties of ground nut. Indian J. Agric. Sci. 56, 816-821.

Ekren, S. (2007). Investigation on the factors affecting the yield and quality of the Ege region tobaccos. PhD thesis. Department of Field Crops, Graduate Faculty of Natural and Applied Science, Ege University, İzmir.

Er, C. and M. Yildiz (2014). Stimulant plants. Ankara University, No: 419, Ankara.

Esendal, E., A.K. Ayan, S. Aytac and N. Camas. (2001). Analysis of some characteristics of tobacco lines collected from Bafra population. Turkey 4. Field Crop Conference, 17-21 September, 2, 267-272, Tekirdag (Turkey).

Espinoza, F.A., J.M. Oliver, B.S. Wilson and S.L. Steinberg. (2012). Using hierarchical clustering and dendrograms to quantify the clustering of membrane proteins. Bull. Math. Biol. 74(1):190211. doi: 10.1007/s11538-011-9671-3.

FAO. (2018). FAOSTAT. Crops. Retrieved in June, 13, 2018 from http://www.fao.org/

Gencer, A.S. (2002). The identification of some characteristics in Turkish tobacco population I: Marmara and Black Sea Regions. Anadolu J. The Aegean Agricultural Research Institute, 12(1): 83-95.

Johnson, H.W., H.F. Robinson and R.W. Comstock (1955). Estimates of genetic and environment variability in Soybean. Agron. J. 47, 314-318.

Kinay, A. (2010). Effects of different nitrogen rates on yield and quality of tobacco (Nicotiana tabacum L.). M.Sc. thesis. Department of Field Crops, University of Gaziosmanpaşa, Tokat (Turkey).

Kinay, A. and G. Yilmaz (2016). Effects of heterosis on agronomically 1mportant traits of oriental tobacco (Nicotiana tabacum L.) hybrids. Suleyman Demirel University J. The Faculty of Agriculture, 11(1): 89-94.

Knapp, H. (2017). Correlation and regression - Pearson. SAGE Publications, Inc, Thousand Oaks, United States.

Korkmaz, A. (2006). A research on agronomic and quality properties of some tobacco varieties in the transitional zone of Aegean region. M.Sc. thesis. Department of Field Crops, University of Ege, İzmir (Turkey).

Kucukozden, R., A. Peksuslu and S. Sekin (2002). Yield and quality characters of İzmir type tobacco cultivars in İzmir Region of Turkey. II. Balkan Scientific Conference Quality and Efficiency of the Tobacco Production, Treatment and Processing, September, Plovdiv/Bulgaria.

Kurt, D. (2011). Effect of the different fertilizer sources and doses on yield and quality in organic tobacco production. M.Sc. thesis. Department of Field Crops, University of Ondokuz Mayıs, Samsun (Turkey).

Kurt, D. and A.K. Ayan (2014). Effect of the different organic fertilizer sources and doses on yield in organic tobacco (Nicotiana tabacum L.) production. J. The Agricultural Faculty of Gaziosmanpasa University, 31(2): 7-14.

Lira, E.G., R. F. Amabile, M. Fagioli and A.P.L. Montalvão (2017). Genetic parameters, phenotypic, genotypic and environmental correlations and genetic variability on sunflower in the Brazilian Savannah. Ciência Rural, 47: 17.

Mouradov, A., F. Cremer and G. Coupland (2002). Control of flowering time: interacting pathways as a basis for diversity. Plant Cell. 14: 111-130.

Malek, M.A., M.Y. Rafii, M.S.S. Afroz, U.K. Nath and M.M.A. Monda (2014). Morphological characterization and assessment of genetic variability, character association, and divergence in soybean mutants. Sci. World J. 2014: 1-12.

Ozel, A. and M. Ozguven (1996). Effect of planting distance and topping height on yield and some charactersof burley tobacco. Çukurova J. Agricultural and Food Sciences, 11(1): 59-72.

Peksuslu, A. (1998). The Morphological physiological and biochemical characteristics of some Turkish tobacco varieties in İzmir-Bornova conditions. $\mathrm{PhD}$ thesis. Department of Field Crops, University of Ege, İzmir (Turkey).

Peksuslu, A., I. Yilmaz, A. İnal and H. Kartal (2012). Tobacco genotypes of Turkey. J. Aegean Agricultural Research Institute, 22(2): 82-90.

Rezitis, A.N. and A.B. Brown (1999). Pass-through of exchange rates and tariffs in Greek-US tobacco trade. Agric. Econ. 21: 269-277.

Singh, B. (2001). Plant Breeding: Principles and Methods, 6th ed., Kalyani Publishers, New Delhi, India.

Steel, R.G.D, J.H. Torrie and D.A. Dickey (1997). Principles and Procedures of Statistics-A Biometrical Approach. McGraw-Hill, New York. 
TEA. (2018). The size of the tobacco leaf. Tobacco Experts Association, Retrieved in July, 16, 2018 from

http://www.tutuneksper.org.tr/kaynaklar/eksperti z/tutun-yapraginin-buyuklugu.

TSI. (2018). Turkish Statistical Institute. Retrieved in June, 6, 2018, from https://biruni.tuik.gov.tr.

TSM. (2016). Turkish State Meteorological Service, Bolu.

TTS. (2006). TS-1000, Turkish Tobacco Standard. Ics 65. December 180 Turkish Tobacco.
Usturali, A., R. Apti, H. Otan, G. Yazan and H. Sengul (1998). Selection studies on sarıbağlar subpopulation in the aegean tobacco region. J. Aegean Agricultural Research Institute, 8(1): 115.

Yagac, C. (2015). Determination of yield and quality characters of tobacco cultivars of Aegean region in Denizli conditions. M.Sc. thesis. Department of Field Crops, University of Tekirdağ Namık Kemal, Tekirdağ (Turkey). 